\title{
Survival by Promise: \\ Dystopian Fiction as Denouncer of the Capitalocene
}

Eduardo Marks de Marques ${ }^{a}$ (D)

\begin{abstract}
The rise of dystopian fiction in the past forty years is revealing of sociopolitical anxieties of the present, many of which can be interpreted as consequences of a capitalist form of organization. Through those narratives, literature has the power to make explicit such tensions, especially those now brought together by the contemporary perception of the Capitalocene. The objective of this paper, thus, is twofold: to discuss the possibilities of acknowledging dystopian fiction as an autonomous genre, and to examine how it exposes the ever-dynamic machinations of capitalism. To that end, several examples from modern and contemporary dystopian novels in English are presented and discussed.
\end{abstract}

Keywords: Dystopian fiction. Capitalocene.

Capitalism and literature. Utopia and dystopia. 
Much attention has been given to the rise of dystopian fiction in the first two decades of the $21^{\text {st }}$ century as though such a rise is a new phenomenon in a genre that had allegedly been dormant since the end of the 1960s (or, if one considers the second-wave feminist incursions in the field, since the late 1970s or mid-1980s). Part of this apparent novelty may be connected to the fact that the earliest examples of this resurgence were targeted at young adult readers. Novels such as Suzanne Collins's The Hunger Games (2008), Veronica Roth's Divergent (2011), and Scott Westerfield's Uglies (2005) (as well as the respective sequels to all three titles), initially dismissed from serious, academic analyses due to their intended audiences, bring about important political questions which, at hindsight, have helped pave the way to more recent (serious, adultoriented) dystopian fiction. Since then, dystopian fiction has been granted the terrifying status of prophecy, especially the trend of climate fiction, or cli-fi, a (possibly) dystopian subgenre that deals with (or speculates) the potentially apocalyptic impacts of climate change on Earth, but some special attention needs to be given to the political implications of the recent rise of extremist far-right political groups in the West, particularly in Europe, United States, and Brazil. This political scenario also allows dystopian fiction to be read prophetically, given the genre's potential to bring "signs of fire ahead" (HILÁRIO, 2013, p. 202).

However, a more careful reading of dystopian fiction allows readers to see that all trends connected to it can be to historical moments of rupture and discontinuity, which, in turn, may be read as rearrangements of structures of power (political and/or economic) aiming at the maintenance of capitalism as a means or socioeconomic organisation. Such shifts depend on the reinvention of humankind (Anthropos) and whose actions have already left physical scars on the planet. The proposition that we now live in a new geological era called the Anthropocene, marked by the human presence and manipulation of the space that surrounds us has been gaining momentum in the humanities for the past twenty or so years, although there still are several different approaches to what it is or when it started. Whether the Anthropocene started with the development of agriculture or with the Industrial Revolution is of little interest once, from the debates around 
it, a new term emerges: Capitalocene. As the name suggests, the Capitalocene, the age of Capital, is a term which "signifies capitalism as a way of organizing nature - as a multispecies, situated, capitalist world-ecology" (MOORE, 2016, p.6) and, thus, places on capitalism the responsibility (or blame, perhaps) for the decline of the Earth and a possible pathway to human extinction. Jason W. Moore (2005) states that:

The Capitalocene argument says three things that the Anthropocene perspective does not-and cannot. First, it insists that the history of capitalism is a relation of capital, power, and nature as an organic whole. It is world-ecological (...). It is a multispecies affair. Capitalism is neither a purely economic nor social system, but "a historically situated complex of metabolisms and assemblages" (...). Second, the history of capitalism cannot be reduced to the burning of fossil fuels, in England or anywhere else. It is a history of the relations of power and re/production premised on the cash nexus. Those relations enfolded coal and other energy sources from the sixteenth century; they allowed for successive waves of global conquest and the worldwide appropriations of Cheap Nature. Third, the Capitalocene argument challenges the Eurocentric-and frankly falseview of capitalism as emerging in England during the eighteenth century. (MOORE, 2005, p. 81)

The Capitalocene, thus, emerges from an understanding that capitalism is inherent to modern human history, a view that needs further discussing.

It is important to limit the scope of what can be understood as capitalism. As stated by historian Eric Hobsbawn in the introduction to his The Age of Capital (1977):

In the 1860s a new word entered the economic and political vocabulary of the world: 'capitalism'... the global triumph of capitalism is the major theme of history in the decades after 1848. It was the triumph of a society which believed that economic growth rested on competitive private enterprise, on success in buying everything in the cheapest market (including labour) and selling in the dearest. An economy so based, and therefore resting naturally on the sound foundations of a bourgeoisie composed of those whom energy, merit and intelligence had raised to their position and kept there, would - it was believed - not only create a world of suitably distributed material plenty, but of ever-growing enlightenment, reason and human opportunity, an advance of the sciences and the arts, in brief a world of continuous and 
accelerating material and moral progress. The few remaining obstacles in the way of the untrammelled development of private enterprise would be swept away. The institutions of the world, or rather of those parts of the world not still debarred by the tyranny of tradition and superstition or by the unfortunate fact of not having white skins (preferably originating in the central and north-western parts of Europe), would gradually approximate to the international model of a territorially defined 'nation-state' with a constitution guaranteeing property and civil rights, elected representative assemblies and governments responsible to them, and, where suitable, a participation in politics of the common people within such limits as would guarantee the bourgeois social order and avoid the risk of its overthrow. (HOBSBAWN, 1977, p. 13)

Essentially, Hobsbawn defines capitalism as both a form of socio-political organization and, also, the discourse on which it stands, based on a set of values presented as positive, desirable and, most importantly, achievable but whose materialisation would never be reached. In fact, the historian suggests that all those values - material plenty, individual liberties, artistic and scientific development, democracy - are actually attached to the best of all possible worlds, obviously from a white Eurocentric perspective. Capitalism, therefore, is a never-fulfilled promise; one that depends on an ever-changing set of circumstances to remain presenting its materialisation on the utopian horizon. Capitalism is aware of (and agrees with) Marx's prophecy that socialism would inevitably follow capitalism as a natural historical event, rather than a human imposition (FARBER, 2008, np.) and, as such, finds ways to remain incomplete.

In this sense, considering literature as an art form that deals directly with and from socio-political anxieties, it is fair to affirm that dystopian literature is a genre with specific internal and external features. Not only does it deal with the intricate, ambivalent co-dependence of the locus of dreams (utopia) and the locus of nightmares (dystopia) (MOHR, 2007, p. 13-15), dislocating political anxieties from the contemporary moment of its creation to another time, usually future (VIEIRA, 2010, p. 26), usually portraying totalitarian regimes (CLAYES, 2010, p. 119-120), following a one-person fight against a regime which creates an illusory enclave of resistance only to realise that this is a tool operated by the very regime that cannot be 
defeated; dystopian fiction shows what is rather than what can be a result of the oppressive social disposition of capitalism.

Knowing that dystopian fiction is connected to the present time of its creation is important as it develops its own historicity. Whenever literary dystopias are discussed, John Stuart Mill's parliament speech in 1868 is often cited as the official coining of the term from an etymological standpoint, but little to no attention is given to the reason why he used the word. A fierce proponent of utilitarianism, a politicalphilosophical doctrine that states that righteous morality is directly proportional the good any action can produce, Mill, dubbed "the most influential English language philosopher of the nineteenth century" (MACLEOD, 2016, np), had been involved in denouncing the harmful effects of English law over Ireland at least since the Great Potato Famine of the mid-1840s. The Irish Land Question, name given to the debate over the many acts preventing and forbidding Roman Catholics - most of the Irish population - from owning land and the apparent lack of parliamentary action to address that issue accordingly was the topic of the aforementioned speech on 12 March 1868:

I may be permitted, as one who, in common with many of my betters, have been subjected to the charge of being Utopian, to congratulate the Government on having joined that goodly company. It is, perhaps, too complimentary to call them Utopians, they ought rather to be called dys-topians, or cacotopians. What is commonly called Utopian is something too good to be practicable; but what they appear to favour is too bad to be practicable. Not only would England and Scotland never submit to it, but the Roman Catholic clergy of Ireland refuse it. They will not take your bribe... As in many other things I differ from the honourable and learned Member for Oxford (Mr. Neate), who moved the Amendment, so my opinion on the subject of Irish remedies is directly contrary to his. Whereas the honourable and learned Member thinks that the real obstacle to the peace and prosperity of Ireland is the proposal of extravagant and impossible remedies, my opinion, on the contrary, is that the real obstacle is not the proposal of extravagant and impossible remedies, but the persistent unwillingness of the House even to look at any remedy which they have pre-judged to be extravagant and impossible... When a country has been so long in possession of full power over another, as this country has over Ireland, and still leaves it in the state of feeling which now exists in Ireland, there is a strong presumption that the remedy required must be much stronger and more drastic than any 
which has yet been applied... All the presumption is in favour of the necessity of some great change. Great and obstinate evils require great remedies. If the House does not think so - if it still has faith in small remedies, I exhort it to make haste and adopt them. It has already lost a great deal of time. (MILL, 1988 [1868], np)

Mill creates the word dystopia, as opposed to the good (albeit non-existing) place utopia represents, to denounce the centuries of colonial rule of England and Scotland over Ireland, claiming the plans being in debate on that occasion "too bad to be practicable". From this brief understanding, it becomes possible to state that dystopia is a by-product of colonialism and, thus, a political entity in its own term.

The political aspects of dystopia as a constant, even formative element of European history are the basis of Gregory Claeys's monograph Dystopia: A Natural History (2017). Despite the modern association between dystopia (historical and literary) with totalitarian regimes, stemmed from secular pessimism (CLAEYS, 2017, p. 4-5), the Professor Emeritus of History analyses dystopianism as a political condition that needs to be thought away from the commonly evoked images of post-apocalyptic societies by suggesting that there are important psychological and sociological bases to its uprising. However, other than totalitarianism, Claeys lists five other models pertinent to modern collectivist political dystopia: militarized societies, slavery, despotism, prisons, and diseased spaces (CLAEYS, 2017, p. 10) that, together with the social paranoia fuelled by religion (CLAEYS, 2017, p. 15-18), allow the author to look into group psychology, with a focus on the concept of crowd, as central to understanding dystopia, which will be discussed in more detail at a later section. What is important to state here is that all the models listed by Clayes are, essentially, elements for the maintenance of capitalism.

Usually presented as one of the modern blueprints for literary dystopias, Aldous Huxley's Brave New World (1932) is a fine example of the intricate and intrinsic connections between dystopia, literature, and society. In the foreword to the second edition, published in 1946 - fourteen years after its launch and one year after the end of World War II - Huxley revisits its premonitory character though, ironically, referring to the World State as utopian: 
All things considered it looks as though Utopia were far closer to us than anyone, only fifteen years ago, could have imagined. Then, I projected it six hundred years into the future. Today it seems quite possible that the horror may be upon us within a single century. That is, if we refrain from blowing ourselves to smithereens in the interval. Indeed, unless we choose to decentralize and to use applied science, not as the end to which human beings are to be made the means, but as the means to producing a race of free individuals, we have only two alternatives to choose from: either a number of national, militarized totalitarianisms, having as their root the terror of the atomic bomb and as their consequence the destruction of civilization (or, if the warfare is limited, the perpetuation of militarism); or else one supranational totalitarianism, called into existence by the social chaos resulting from rapid technological progress in general and the atomic revolution in particular, and developing, under the need for efficiency and stability, into the welfare-tyranny of Utopia. You pays (sic) your money and you takes (sic) your choice. (HUXLEY, 2004 [1946], p. 13)

Huxley's novel embraces capitalism as both religion and science. By electing Henry Ford as Christ - Brave New World is set in the year 632 after Ford (HUXLEY, 2004, p. 16), placing the development of the conveyor belt - and, consequently, the introduction of mass-production techniques, marking the birth of a more rational, cost-oriented capitalism - as ground zero for highly technological advances. In fact, the London in the novel is in many aspects a materialisation of the promises of capitalism presented by Hobsbawn earlier. The utopian promises of the capital only exist as discourse, never as materialisation, which allows us to recognize the proximity between utopia and dystopia. Both conceive of ideal harmonious groups that privilege close connections between individuals and the unity and interdependence they exhibit. A key question here is how inclusive or exclusive this exchange of benefits is. Typically, the collectivist dystopia assumes two main forms: the internal, where coercion pervades the privileged group; and the external, where coercion defines the relationship to outsiders as a means of upholding the leading group, who are, however, free of most of the repression inflicted upon outsiders. In both cases, however, equality and plenty are enjoyed by some groups at the expense of others. (CLAEYS, 2017, p. 7-8), showing that there are utopian enclaves inside every dystopian society. 
One important argument for the suggestion that dystopias are more than just a literary by-product of capitalism can be found in the then-controversial, now-overcome thesis of the end of history developed by Francis Fukuyama in his 1992 book The End of History and the Last Man. When Fukuyama's argument was first presented as an article in 1989, it sparked controversy when major events such as the fall of the Berlin Wall in 1991, the Tianmen Square Massacre in 1989, and the invasion of Kuwait by Iraq in 1990 took place as critics stated that such events proved that history was not (and would never be) over. However, Fukuyama clarifies it in the introduction to his book:

And yet what I suggested had come to an end was not the occurrence of events, even large and grave events, but History: that is, history understood as a single, coherent, evolutionary process, when taking into account the experience of all peoples in all times. This understanding of History was most closely associated with the great German philosopher G. W. F. Hegel. It was made part of our daily intellectual atmosphere by Karl Marx, who borrowed this concept of History from Hegel, and is implicit in our use of words like "primitive" or "advanced," "traditional" or "modern," when referring to different types of human 'societies. For both of these thinkers, there was a coherent development of human societies from simple tribal ones based on slavery and subsistence agriculture, through various theocracies, monarchies, and feudal aristocracies, up through modern liberal democracy and technologically driven capitalism. This evolutionary process was neither random nor unintelligible, even if it did not proceed in a straight line, and even if it was possible to question whether man was happier or better off as a result of historical "progress." (FUKUYAMA, 1992, p. xii)

Essentially, Fukuyama's argument is that the end of the Cold War brought about the victory of liberal democracies against its many contenders, which somehow carried the common idea of History as a fundamental force towards change (aiming at evolution not necessarily reaching it), usually connected to Marxism. Therefore, the collapse of Communism, the author believes, marks a new, never-before-seen, era of universal peace amongst nations:

We who live in stable, long-standing liberal democracies face an unusual situation. In our grandparents' time, many 
reasonable people could foresee a radiant socialist future in which private property and capitalism had been abolished, and in which politics itself was somehow overcome. Today, by contrast, we have trouble imagining a world that is radically better than our own, or a future that is not essentially democratic and capitalist. Within that framework, of course, many things could be improved: we could house the homeless, guarantee opportunity for minorities and women, improve competitiveness, and create new jobs. We can also imagine future worlds that are significantly worse than what we know now, in which national, racial, or religious intolerance makes a comeback, or in which we are overwhelmed by war or environmental collapse. But we cannot picture to ourselves a world that is essentially different from the present one, and at the same time better. Other, less reflective ages also thought of themselves as the best, but we arrive at this conclusion exhausted, as it were, from the pursuit of alternatives we felt had to be better than liberal democracy. (FUKUYAMA, 1992, p.46)

In other words, Fukuyama defended the argument that the end of history brings with it both the materialisation of utopia and the consolidation of dystopia as an exercise of imagination by stating that one cannot imagine a world better than the current one (from 1992 standards).

Needless to say that such an argument is flawed from its foundation and has since been revised but, for the sake of the argument here, two claims deserve developing. First, that the alleged victory of liberal democracies over its counterparts is, ultimately, a victory of capitalism over socialism/communism and, thus, the materialisation of utopia presented by Fukuyama is the consolidation of that system of socio-political organisation. Secondly, that the consolidation of such utopia destroys any possibilities of its downfall. A superficial reading of both claims already allows them to be questioned and debunked, but I would like to propose a different approach. Initially, it must be understood that utopias have never relied on a sense of universal equality amongst their members. Any classic examples of utopian literature, such as Plato's Republic (c.575 BC) or Thomas More's Utopia (1518) show readers that both division of labour, and class distinction are fundamental for the maintenance of utopia, which are key elements of modern dystopian novels such as Brave New World. Huxley's novel presents us the World State's operation and functioning on a 


\section{necessary division between castes, from Alphas to Epsilons, created as such on purpose in hatcheries:}

‘We also predestine and condition. We decant our babies as socialized human beings, as Alphas or Epsilons, as future sewage workers or future...' He was going to say 'future World Controllers,' but correcting himself, said 'future Directors of Hatcheries' instead...

'Reducing the number of revolutions per minute,' Mr. Foster explained. 'The surrogate goes round slower; therefore passes through the lung at longer intervals; therefore gives the embryo less oxygen. Nothing like oxygen-shortage for keeping an embryo below par.' Again he rubbed his hands.

'But why do you want to keep the embryo below par?' asked an ingenuous student.

'Ass!' said the Director, breaking a long silence. 'Hasn't it occurred to you that an Epsilon embryo must have an Epsilon environment as well as an Epsilon heredity?'

It evidently hadn't occurred to him. He was covered with confusion.

'The lower the caste,' said Mr. Foster, 'the shorter the oxygen.' The first organ affected was the brain. After that the skeleton. At seventy per cent. of normal oxygen you got dwarfs. At less than seventy, eyeless monsters.

'Who are no use at all,' concluded Mr. Foster.

Whereas (his voice became confidential and eager), if they could discover a technique for shortening the period of maturation what a triumph, what a benefaction to Society!

'Consider the horse.'

They considered it.

Mature at six; the elephant at ten. While at thirteen a man is not yet sexually mature; and is only full grown at twenty. Hence, of course, that fruit of delayed development, the human intelligence.

'But in Epsilons,' said Mr. Foster very justly, 'we don't need human intelligence.'

Didn't need and didn't get it. But though the Epsilon mind was mature at ten, the Epsilon body was not fit to work till eighteen. Long years of superfluous and wasted immaturity. If the physical development could be speeded up till it was as quick, say, as a cow's, what an enormous saving to the Community! (HUXLEY, 2004 [1932], p. 23-25) 
Inequality is, thus, paramount not only to dystopian societies but to utopian ones as well. In his book Capital and Ideology (2020), French economist Thomas Piketty examines the advent of what he refers to as "hypercapitalism", the current stage of neoliberal globalisation where meritocratic discourses within a highly mobile, little-regulated international flow of capital (PIKETTY, 2020, p. 649). Piketty's main argument is that capital, the building block of capitalism, has as its main goal the maintenance of inequalities, and they can be perceived in every dystopian novel. Even in Orwell's Nineteen Eighty-Four (1949), usually misread as a warning against socialism/communism rather than a warning against totalitarian regimes, can we see such inequalities as we perceive the ideology of those in the inner circle of the Party is different from those of the outer circle.

The maintenance of inequalities needs to be continuously followed by a seductive narrative or, else, it might trigger a revolution. In fact, capitalism is in ongoing change, in what Joyce Appleby (2010) refers to as "the relentless revolution" in her book The Relentless Revolution: A History of Capitalism. And this is where dystopian fiction meets capitalism from a historical (and one might add, even historiographic) standpoint: not only is the history of dystopian communities unknown (and here I am not suggesting that these novels should have expanded their narratives to incorporate a historical background) but the powers that be must constantly find ways to erase any forms of historical consciousness, whether by changing historiographic narratives, as is Winston Smith's role in the ironically named Ministry of Truth in Orwell, or by connecting history of things past to unbearable mental and physical anguish and pain, as one can see in Lois Lowry's The Giver (1993), where we are presented to a society where only one individual carries the memories of the entire history of humankind; or even by connecting remembrance and punishment, as one can see in Suzanne Collins's The Hunger Games, where the reality show that is in fact a Battle Royale is the ultimate form of subjugation of any revolutionary drive in a postmodern rendering of the panis et circensis policy of ancient Rome.

Even more relevant than the manipulation of a narrative of an eternal present, dystopias also rely on the belief that whatever changes that may have led to the current state of 
events are the result of natural evolution, albeit of a flawed pathway. Even in novels that hint at revolutions or coups d'état at the origin of their society suggest that they were mere reactions against a twisted status quo. This is what we see, for instance, in Margaret Atwood's The Handmaid's Tale (1985), where, through Offred's fragmented narrative, readers learn that Gilead is but a reaction aimed at restoring values that were being allegedly destroyed by second-wave feminism, symbolised primarily by the narrator's mother.

The main point here is that the discourses that connect capitalism with human nature are the bases of even counterargumentative analyses. In fact, the idea of human nature is on the basis of Marxist thought itself. In his Theses on Feuerbach (1845), Marx states that:

Feuerbach resolves the essence of religion into the essence of man. But the essence of man is no abstraction inherent in each single individual. In its reality it is the ensemble of the social relations. Feuerbach, who does not enter upon a criticism of this real essence, is hence obliged: 1 . To abstract from the historical process and to define the religious sentiment by itself, and to presuppose an abstract - isolated - human individual. 2. Essence, therefore, can be regarded only as 'species', as an inner, mute, general character which unites the many individuals in a natural way. (MARX, 1969 [1845], p. 14)

His comment on the work of philosopher Ludwig Feuerbach has historically been understood by later commentators such as Louis Althusser that Marxism claims human essence is incompatible with historical materialism, a statement later criticised by political theorist Norman Geras in his 1983 book Marx and Human Nature: Refutation of a Legend. By then, though, the damage had already been done: at that time, the belief that whatever nature would bind humans together was not only incompatible with one of the pillars of socialism but, and most importantly, could prove the point that capitalism was inherent to the human race. In fact, to this day, this belief still circulates as a way to defend the maintenance of capitalism. In his article "Capitalism and Human Nature" (2005), political theorist Will Wilkinson brings elements of the fields of evolutionary and cognitive psychology to defend that idea. Thus, if capitalism is natural to humankind, a critical history of its becoming is not only irrelevant but also (and 
perhaps mainly) dangerous, as is the case with dystopian societies.

Because dystopian historicity is so diffuse within the narratives that it becomes virtually impossible to retrieve it, and since temporal displacement into the future is a common trend within dystopias, it is quite common to mistake dystopia with science fiction. Much of the confusion ordinary and critical readers may have in categorising dystopian fiction either as a genre or as a subgenre of sci-fi (or its contemporary offspring, speculative fiction) (MARKS DE MARQUES, 2014, p.13) can be traced back to the end of the $19^{\text {th }}$ century, with the publication of H.G. Wells's The Time Machine (1895), a novel which has since been seen as part of the birth of modern science fiction. It presents readers to a young nameless scientist who defends that time is another dimension and, as such, it allows movement within itself. The novel then recounts the Time Traveller's narrative to the year A.D. 802,701 and his experiences with two societies: the Eloi and the Morlock. The former are an intelligent, well-organised society living aboveground, who suffer from the attacks of the latter, monstrous ape-like barbarians who live underground. The Time Traveller's initial impressions of this strange time (for the time machine allows only travels through time, not space) are symptomatic of the discussion to follow:

'As I walked I was watching for every impression that could possibly help to explain the condition of ruinous splendour in which I found the world-for ruinous it was. A little way up the hill, for instance, was a great heap of granite, bound together by masses of aluminium, a vast labyrinth of precipitous walls and crumpled heaps, amidst which were thick heaps of very beautiful pagoda-like plants-nettles possibly-but wonderfully tinted with brown about the leaves, and incapable of stinging. It was evidently the derelict remains of some vast structure, to what end built I could not determine. It was here that I was destined, at a later date, to have a very strange experience-the first intimation of a still stranger discovery-but of that I will speak in its proper place.

'Looking round, with a sudden thought, from a terrace on which I rested for a while, I realised that there were no small houses to be seen. Apparently the single house, and possibly even the household, had vanished. Here and there among the greenery were palace-like buildings, but the house and the 
cottage, which form such characteristic features of our own English landscape, had disappeared.

“Communism,” said I to myself. (WELLS, 2009 [1895] p. 25)

A socialist himself, Wells, who was a member of The Fabian Society, a British think tank which aims at developing reformist policies for the implementation of democratic socialism, was aware of the impact of class struggle in Britain at the turn of the $19^{\text {th }}$ to the $20^{\text {th }}$ century and the Time Traveller's comment of individual dwellings being replaced by large communal spaces as Communism cannot be seen as a form of critique. In fact, as Orwell would do in later decades, Wells was critical of totalitarianism, something he made clear in the reports to his travels to Moscow in the 1930s; not of communism itself.

The Eloi and the Morlocks play with readers' expectations when, at first, the Time Traveller introduces them as a superior people, living a happy, wealthy, idyllic life as opposed to the latter, whose life underground suggests their sinister traits (HUME, 2005, p. 42). In fact, upon a closer look, we realise that

[w] hen comparing the two races, we find that both have traits associated with ruling and exploiting. The Eloi apparently live off the labor of the Morlocks while the latter apparently live off the flesh of the former. However, both are "feminized" in ways that render them less than masterful. These ambiguities in the cultural symbol system cannot be resolved. The traits associated with each race remain in uneasy tension, and contribute to the difficulty that critics have had in putting labels to the two races. (HUME, 2005, p. 42)

This co-dependence of the Eloi and the Morlocks allows the narrator to suppose that both races are in fact derived from humans: the Eloi from upper-class intellectuals, whose absence of the need of physical labour has dwindled their bodies but, on the other hand, allows them to live aboveground; and the Morlocks from the working classes, whose exploration (and exploitation) by the Eloi becomes the only possible form of survival. The Time Traveller realises that, even more than 800,000 years into the future, capitalism still survives as a marker for the evolution of the species, as Patrick A. McCarthy (2005) states: 
In fact, the Eloi and Morlocks present us with debased versions of two Victorian responses to evolution: the Eloi, like the Aesthetes of the 1890s, have retreated from the struggle for existence into what the Time Traveller calls "art and... eroticism," which lead to "languor and decay" (...), while the Morlocks - descendants of the victims of capitalistic exploitation - have become like the Darwinian apologists for capitalism and imperialism and have reverted to cannibalism, using the weaker Eloi as cattle. The split here also echoes Huxley's warning about the twin dangers of weakness and ruthlessness - the dangers that lie in renouncing our evolutionary heritage, like the Eloi, and being dominated by it, like the Morlocks. (McCARTHY, 2005, p. 201)

The Time Machine, thus, can be read as an early example of a literary rendering of the Capitalocene, a term which "signifies capitalism as a way of organizing nature - as a multispecies, situated, capitalist world-ecology" (MOORE, 2016, p.6) even in a world where humans have changed enough to be seen as a different species but not enough so as to leave traditional structural forms of organisation behind. A similar claim can be posed to science fiction narratives, which themselves may be a subgenre of dystopia instead of the opposite.

Dystopian novels test the limits and limitations of our political imagination and make it explicit that it is unsurmountable primarily because capitalism finds ways to constantly reinvent itself (mainly by the instillment or desire) so that it can always remain relevant. In that regard, capitalism orients many different forms of political organisation, from the more libertarian to the more totalitarian ones, promising its eternal immanence. An example of such connections is found at the end of the final volume of the Hunger Games trilogy, Mockingjay (2010). The trilogy discusses several important political issues such as the division of labour under the premise of specialisation, and the uses of cultural oppression via the Hunger Games. Each of the 13 districts of Panem, the nation formed after a series of unmentioned catastrophes and revolutions in the North American territory, deals with one element of either primary or secondary industry sector whose goods supply exclusively the demands of the opulent, hedonistic Capitol, whose control is maintained by physical (with the presence of the ironically but aptly called Peacekeeper corps. The games, a yearly televised show in which two 
individuals from each district are sent to a deadly arena from where only one survivor must leave, operate on the level of cultural control where Capitol citizens can sponsor the players (or Tributes) they wish to last longer in the competition as a reminder that the districts only exist as long as the needs of those metropolitan citizens are met.

The novels follow the journey of the narrator, Katniss Everdeen, a rebellious teenager from District 12, responsible for the mining of coal, who offers herself as a tribute to save her younger sister who had been drafted, wins the games twice, and is persuaded to be the face and frontline of a revolution led by the thought-defunct District 13 (responsible for nuclear power) to overthrow President Snow and his regime. The imposition of capitalism by its promise of power happens in the final pages of the novel, after the Capitol is seized, President Snow is captured, and the leader of District 13, Alma Coin, becomes the new self-proclaimed president whose first official act is to carry out the public, televised execution of the overthrown president by the hands of the narrator. Right before that, however, Alma Coin discusses her plans: to promote another edition of the Hunger Games, but with Capitol's children, one of whom should be Snow's granddaughter for the amusement of the districts (COLLINS, 2010, p. 368-369). At this point, Katniss realises that the main goal of the revolution she helped promote has never been the alternance of regimes, but the mere alternance of power to maintain the regime albeit with inverted vectors: the Capitol would then be exploited by the districts. In an ultimate act of alleged rebelliousness, Katniss kills Coin, instead (COLLINS, 2010, p. 372), triggering an angry mob to kill Snow, and arrest the protagonist for treason.

The narrative that follows is an example of the illusion of change dystopias operate on as a materialisation of capitalism's flirt with the powers that be:

After I shot Coin, there was pandemonium. When the ruckus died down, they discovered Snow's body, still tethered to the post. Opinions differ on whether he choked to death while laughing or was crushed by the crowd. No one really cares. An emergency election was thrown together and Paylor was voted president. Plutarch was appointed secretary of communications, which means he sets the programming for 
the airwaves. The first big televised event was my trial, in which he was also a star witness. In my defense, of course. (COLLINS, 2020, p. 378)

Presented as a mere narrative detail, an important element of capitalist power stands out in the passage. After the assassination of both Snow and Coin, a new president emerges, by an election (which is unclear whether direct or indirect, although the context of the novel allows readers to imagine the latter) but the form of choice of leadership changes little to nothing as Katniss's trial replaces the Hunger Games as televised entertainment for the masses.

Another interesting example of the deep rooting of capitalist culture within our political imagination can be found in Margaret Atwood's MaddAddam trilogy: Oryx and Crake (2003), The Year of the Flood (2009), and MaddAddam (2013). The novels follow the projected destruction of a technocratic society, where the state had been replaced by major multinational corporations, and towns, by walled complexes named Compounds, whose citizens worked for such scientific companies. The Compounds were responsible for all the most basic aspects of human life: food, housing, education, leisure, and rewarded those who had scientific inclinations while disregarding those with artistic ones, for art does not generate, in such a view of social arrangement, any potentially lucrative goods. In the first novel of the trilogy, the narrative takes place in two moments: a post-apocalyptic present, and the memories of the past. Jimmy, the narrator, recollects his friendship with Crake, a promising young scientist whose real concern is materialised in Project Paradice. The project is twofold: on the one hand, it involves the development of BlyssPluss, a pill which would act as a vaccine against many possible causes of death, provide unlimited libido, and extend youth. However, it would not be made public to people that BlyssPluss's real expected effect was mass sterilization. On the other hand, the project bioengineered hominids, referred to as Crakers, whose DNA is basically human though with alterations that would distance them from how humans usually see ourselves. For instance, Crakers were programmed to be vegan (establishing, thus, a new form of relationship to the planet), to die at age 30 (eliminating, thus, the anxieties of old age), to have sex only for 
procreation (female Crakers would change skin colour when they ovulated), and, most importantly, they would have a quite simple, ahistorical understanding of themselves. Unbeknownst to Jimmy, the BlyssPluss pill also carried a deadly pathogen to which him and the Crakers were immune, revealing Crake's plan: the extinction of humankind and its replacement for his own creation to save the planet. Jimmy was, then, recruited, against his will, to be the guardian of the first generation Crakers after the events of the Waterless Flood, how the event of mass extinction is referred in the following novels of the trilogy.

Oryx and Crake uses the "last man on Earth" trope of post-apocalyptic fiction to show that capitalism always finds a way to survive. Jimmy, the narrator, carries with him the very culture Crake has tried to eliminate - the G-Spot, with the letter standing for God, as a representation of the totality of human culture whose discourse is used to differentiate us from other animal species (ATWOOD, 2003, p.157). However, in order to guarantee his own survival, Jimmy needs aid from the Crakers and, as such, creates a space where symbolic capital can be traded by food. The narrator offers the Crakers a cosmogony (a myth of their own origins) and, in turn, makes the hominids provide him with fish, going against their peaceful, vegetarian nature. A system of exploitation of labour is recreated, albeit in a currency-less world, where words (or storytelling) become capitalised. The restoration of any sense of humanity brings about the restoration of capitalist, or vice-versa.

Dystopia, thus, must be addressed as a mature, autonomous genre, deriving from the presence of capitalism as a force within a human social organisation but, at the same time, exposing the tensions within such an organisation. Acknowledging capitalism as simultaneously utopian and dystopian - or, to use the term coined by Margaret Atwood, "ustopian" (ATWOOD, 2011, p.66) - allows readers of dystopian fiction to see it as more than just a projection of a possible nightmarish future but, mostly, as an example of the mechanisms through which the unfulfilled promises of happiness and material plenty presented by the flow of capital operate. Despite being limited by the boundaries of our political imagination, dystopian fiction must be acknowledged as an important cultural weapon to promote political change. 


\section{REFERENCES}

APPLEBY, Joyce. The Relentless Revolution: A History of Capitalism. New York: W.W. Norton, 2010.

ATWOOD, Margaret. The Handmaid's Tale. New York: Anchor Books, 1985.

. Oryx and Crake. New York: Anchor Books, 2003

. The Year of the Flood. New York: Anchor Books, 2009.

. In Other Worlds: SF and the Human Imagination. London:

Virago, 2011.

. MaddAddam. London: Bloomsbury, 2013.

BOUSON, J. Brooks. "It's Game Over Forever": Atwood's Satiric Vision of a Bioengineered Posthuman Future in Oryx and Crake. In: BLOOM, Harold (Ed.). Bloom's Modern Critical Views: Margaret Atwood. New York: Bloom's Literary Criticism, 2009. p. 93-110.

CLAEYS, Gregory. "The Origins of Dystopia: Wells, Huxley and Orwell". In: CLAEYS, Gregory (ed.). The Cambridge Companion to Utopian Literature. Cambridge: University of Cambridge Press, 2010. 107-131.

Press, 2017.

. Dystopia: A Natural History. Oxford: Oxford University

COLLINS, Suzanne. Mockingjay. New York: Scholastic Press, 2010.

. The Hunger Games. New York: Scholastic Press, 2008.

FARBER, Samuel. "What comes after Capitalism?". International Socialist Review, Issue 63. Available at: https://isreview.org/issue/63/ what-comes-after-capitalism. (Accessed: Dec 12, 2020).

FUKUYAMA, Francis. The End of History and the Last Man. New York: Free Press, 1992.

. Our Posthuman Future: Consequences of the Biotechnology

Revolution. New York: Farrar, Straus and Giroux, 2003. 
GERAS, Norman. Marx and Human Nature: Refutation of a Legend. New York: Verso Books, 1983.

HILÁRIO, Leomir Cardoso. Teoria Crítica e Literatura: a distopia como ferramenta de análise radical da modernidade. Anuário de Literatura, Florianópolis, v.18, n.2, p. 201-215, 2013.

HOBSBAWM, Eric J. The Age of Capital - 1848-1875. London: Abacus, 1975.

HUME, Kathryn. Eat or Be Eaten: H.G. Wells's The Time Machine. In: BLOOM, Harold (ed.). H.G. Wells. Philadelphia: Chelsea House Publishers, 2005. p. 35-51.

HUXLEY, Aldous. Brave New World. New York: HarperCollins, 2004 [1932].

. Brave New World Revisited. New York: HarperCollins, 2004 [1946].

LOWRY, Lois. The Giver. Boston: Houghton Mifflin, 1993.

MACLEOD, Cristopher. John Stuart Mill. In: ZALTA, Edward N. (Ed.). Stanford Encyclopedia of Philosophy. Palo Alto: Stanford UP, 2020. Available at: https://plato.stanford.edu/archives/sum2020/ entries/mill/. Accessed: Dec 4, 2020.

MARKS DE MARQUES, Eduardo. "'God is a cluster of neurons': Neo-posthumanism, theocide, theogony and anti-myths of origin in Margaret Atwood's Oryx and Crake". Gragoatá, Niterói, n. 35, p. 155-169, 2. sem. 2013.

. Da Centralidade Política à Centralidade do Corpo Transumano: Movimentos da Terceira Virada Distópica na Literatura. Anuário de Literatura, Florianópolis, v.19, n.1, p. 1019, 2014.

. I Sing the Body Dystopic: Utopia and Posthuman Corporeality in P.D. James's The Children of Men. Ilha do Desterro, Florianópolis, n. 65, p.29-48, jul/dez 2013.

MARX, Karl. Marx / Engels - Selected works, Vol. 1. Moscow: Progress Publishers, 1969. 
McCARTHY, Patrick A. Heart of Darkness and the Early Novels of H.G. Wells: Evolution, Anarchy, Entropy. In: BLOOM, Harold (ed.). H.G. Wells. Philadelphia: Chelsea House Publishers, 2005. p. 193-216.

MILL, John Stuart. The Collected Works of John Stuart Mill, Volume XXVIII - Public and Parliamentary Speeches Part I November 1850 - November 1868. Ed. John M. Robson and Bruce L. Kinzer. London: Routledge, 1988.

MOHR, Dunja M. Transgressive Utopian Dystopias: The Postmodern Reappearance of Utopia in the Disguise of Dystopia. Zeitschrift für Anglistik und Amerikanistik (ZAA), Leipzig, n. 55.1, p.5-24, 2007.

MOORE, Jason W. Introduction: Anthropocene or Capitalocene? Nature, History, and the Crisis of Capitalism. In: MOORE, Jason W. (ed.). Anthropocene or Capitalocene? Nature, History, and the Crisis of Capitalism. Oakland: PM Press, 2016. p. 1-11.

The Rise of Cheap Nature. In: MOORE, Jason W. (ed.). Anthropocene or Capitalocene? Nature, History, and the Crisis of Capitalism. Oakland: PM Press, 2016. p. 78-115.

ORWELL, George. Nineteen Eighty-Four. London: Penguin Books, 2003 [1949].

PALSSON, Gilsi et al. Reconceptualizing the "Anthropos" in the Anthropocene: Integrating the Social Sciences and Humanities in Global Environmental Change Research. Environmental Science E Policy, 28, p. 3-13 2013.

PIKETTY, Thomas. Capital and Ideology. Traduzido por Arthur Goldhammer. Cambridge, MA: The Belknap Press of Harvard University Press, 2020.

WELLS, H.G. The Time Machine. Norton Critical Edition. New York: W.W. Norton, 2009 [1895].

WESTERFIELD, Scott. Uglies. New York: Simon Pulse, 2006.

WILKINSON, Will. "Capitalism and Human Nature". CATO Policy Report, Vol. XXVII, n.1, p. 1-15, Jan/Feb 2005. 


\section{RESUMO}

\section{Sobrevivência por Promessa:}

\section{Ficção Distópica como Denúncia do} Capitaloceno

O advento da ficção distópica nos últimos quarenta anos é revelador de ansiedades sociopoliticas do presente, muitas das quais podem ser interpretadas como consequências de uma forma de organização capitalista. Através destas narrativas, a literatura tem o poder de explicitar tais tensões, em especial aquelas agora retratadas pela percepção contemporânea do Capitaloceno. O objetivo deste trabalho, assim, é duplo: discutir as possibilidades de reconhecimento da ficção distópica como um gênero autônomo e examinar como ela expõe as maquinações constantemente dinâmicas do capitalismo. Para tal fim, vários exemplos de romances distópicos modernos e contemporâneos escritos em inglês são apresentados e discutidos.

Palavras-chave: Ficção distópica.

Capitaloceno. Capitalismo e literatura. Utopia e distopia.

Eduardo Marks de Marques é doutor em Australian Literature and Cultural History pela University of Queensland (Austrália) e realizou estágio pós-doutoral em Estudos Literários na Universidade Federal de Minas Gerais. É professor de literaturas de língua inglesa e teoria literária no Centro de Letras e Comunicação da Universidade Federal de Pelotas (UFPel). Desenvolve pesquisas na área de distopias literárias e suas intersecções com pós-humanismo, transumanismo e antropoceno desde 2013. 